\title{
Infantile to late adulthood onset facioscapulohumeral dystrophy type 1: a case series
}

WY Leung ${ }^{1}$, MB, BS, MRCPCH, HM Luk ${ }^{2}$, FHKCPaed, FHKAM (Paediatrics), Varut Vardhanabhuti ${ }^{3}$, PhD (UK), FRCR (UK), Y Ga0 ${ }^{4}$, PhD, FHKCP (Neurology), FHKAM (Medicine), KF Hui 5 , FHKCP (Neurology), FHKAM (Medicine), WY Lau 6 , FHKCP (Neurology), FHKAM (Medicine), Terence PH Young ${ }^{7}$, FHKCP (Neurology), FHKAM (Medicine), Jessica TC Li ${ }^{8}$, FHKCP (Neurology), FHKAM (Medicine), Eva LW Fung ${ }^{9}$, FHKCPaed, FHKAM (Paediatrics),

Annie TG Chiu', FHKCPaed, FHKAM (Paediatrics), Ivan FM Lo², FHKCPaed, FHKAM (Paediatrics), Brian HY Chung'1, FHKAM (Paediatrics), FCCMG (Clinical Genetics, Canada), YF Cheung ${ }^{8}$, FHKCP (Neurology), FHKAM (Medicine), Sophelia HS Chan ${ }^{1 *}$, FHKCPaed, FHKAM (Paediatrics)

${ }^{1}$ Department of Paediatrics and Adolescent Medicine, Queen Mary Hospital, The University of Hong Kong, Hong Kong

${ }^{2}$ Clinical Genetic Service, Department of Health, Hong Kong SAR Government, Hong Kong

${ }^{3}$ Department of Diagnostic Radiology, The University of Hong Kong, Hong Kong

${ }^{4}$ Department of Medicine, Queen Mary Hospital, Hong Kong

${ }^{5}$ Department of Medicine and Geriatrics, United Christian Hospital, Hong Kong

${ }^{6}$ Department of Medicine and Geriatrics, Kwong Wah Hospital, Hong Kong

${ }^{7}$ Department of Medicine and Geriatrics, Ruttonjee \& Tang Shiu Kin Hospitals, Hong Kong

${ }^{8}$ Department of Medicine, Queen Elizabeth Hospital, Hong Kong

${ }^{9}$ Department of Paediatrics, Prince of Wales Hospital, Hong Kong

*Corresponding author: sophehs@hku.hk

Hong Kong Med J 2021;27:444-9

https://doi.org/10.12809/hkmj209001

\section{Cases}

We present the clinical data of eight patients with genetically confirmed facioscapulohumeral muscular dystrophy type 1 (FSHD1) in Hong Kong (Table).

In June 2015, Patient 1 presented with right ptosis and bilateral sensorineural hearing loss at age 1 year. He had early-onset FSHD1 of the most severe phenotype, with early development of asymmetrical facial and upper limb weakness, significant hearing impairment requiring hearing aids, and an early need for ventilation and feeding support (Fig 1).

In May 2019, Patient 2 presented with progressive asymmetrical facial weakness with predominant upper limb girdle weakness from age 11 years (Fig 2). Magnetic resonance imaging scan was taken at age 13 years (Fig 3).

In September 2014, Patient 3 presented with upper and lower limb proximal muscle weakness from age 18 years. Magnetic resonance imaging scan was taken at age 23 years (Fig 4).

Patients 2 to 8 had insidious onset of muscle weakness during adolescence or adulthood and a slow deterioration of motor function. Asymmetrical muscle involvement was common. Three patients had their lung function assessed of whom two had a restrictive pattern suggestive of expiratory muscle weakness.

Patients 1 and 2 were referred to the neuromuscular disorder clinic of the Department of
Paediatrics and Adolescent Medicine, The University of Hong Kong for diagnostic examination and testing. Patients 3 to 8 were referred to the Clinical Genetic Service of the Department of Health for genetic testing. All DNA diagnostic tests were performed overseas, either self-financed (Patients 3 to 8 with the genetic testing performed in United Kingdom) or through research collaboration with financial support from the 'Diagnosis and therapy development of rare neurological diseases and neuromuscular diseases' fund (Patients 1 and 2, with the genetic testing performed in The Netherlands). For these patients, the diagnosis of FSHD was confirmed by standard genetic testing using Southern blotting and hybridisation with the P13E-11 probe. Restriction enzyme digestion with EcoRI, which recognises the D4Z4 locus on chromosome 4 and 10, was applied. The EcoRI/BlnI digestion further fragments the chromosome 10 array to identify the D4Z4 arrays located on chromosome 4, and the length and number of D4Z4 units were determined.

The median age of disease onset was 14 years (range, 1-32). The male: female ratio was 3:1. The median time between onset of symptoms and genetic diagnosis in this cohort was 16 years (range, 2-44). Of the patients who required a walking stick (Patients 5 to 8), the median age at which the need arose was 47.5 years (range, 43-53). Two patients also required a wheelchair for outdoor mobility, from age 49 and 57 years. None of the patients had hearing problems. 
TABLE. Characteristics of the eight patients with facioscapulohumeral muscular dystrophy type I

\begin{tabular}{|c|c|c|c|c|c|c|c|c|c|c|c|}
\hline $\begin{array}{l}\text { Patient } \\
\text { No. }\end{array}$ & Sex & $\begin{array}{l}\text { Age } \\
\text { at last } \\
\text { visit, y }\end{array}$ & Latest mobility & $\begin{array}{l}\text { D4Z4 units*, } \\
\text { EcoRI size, } \\
\text { EcoRI/BINI } \\
\text { size }\end{array}$ & $\begin{array}{l}\text { Family } \\
\text { history }\end{array}$ & $\begin{array}{l}\text { Age at } \\
\text { symptom } \\
\text { onset, y }\end{array}$ & $\begin{array}{c}\text { Age at } \\
\text { genetic } \\
\text { diagnosis, } \\
y\end{array}$ & $\begin{array}{l}\text { Delay } \\
\text { between } \\
\text { onset and } \\
\text { diagnosis, } \\
y\end{array}$ & Key presentation and progress & $\begin{array}{c}\text { CK } \\
\text { (U/L) }\end{array}$ & $\begin{array}{l}\text { Muscle } \\
\text { biopsy } \\
\text { findings }\end{array}$ \\
\hline 1 & M & 6 & Walk unaided & 2 D4Z4 units & Mother & 1 & 4 & 3 & $\begin{array}{l}\text { - Right ptosis, asymmetrical } \\
\text { facial weakness, bilateral } \\
\text { sensorineural hearing loss, <age } \\
1 \text { year } \\
\text { - UL girdle weakness } \\
\text { - Asymmetrical scapular winging } \\
\text { - Increased LL weakness with age } \\
\text { - Required ventilatory support at } \\
\text { age } 5 \text { years } \\
\text { - Required gastrostomy feeding at } \\
\text { age } 6 \text { years }\end{array}$ & 448 & ND \\
\hline 2 & M & 14 & Walk unaided & $\begin{array}{l}3 \pm 1 \mathrm{D} 4 \mathrm{Z4} \\
\text { units, } 17 \mathrm{~kb} \\
14 \mathrm{~kb}\end{array}$ & None & 11 & 13 & 2 & $\begin{array}{l}\text { - Asymmetrical facial weakness } \\
\text { - Predominant UL girdle } \\
\text { weakness } \\
\text { - Asymmetrical scapular winging }\end{array}$ & 864 & ND \\
\hline 3 & $\mathrm{~F}$ & 25 & Walk unaided & $\begin{array}{l}7 \pm 1 \text { D } 4 Z 4 \\
\text { units, } 32 \mathrm{~kb} \text {, } \\
29 \mathrm{~kb}\end{array}$ & Mother & 18 & 22 & 4 & $\begin{array}{l}\text { - UL and LL girdle weakness } \\
\text { - Significant scapular winging }\end{array}$ & 912 & Dystrophic \\
\hline 4 & M & 22 & Walk unaided & $\begin{array}{l}1 \pm 1 \mathrm{D} 4 \mathrm{Z} 4 \\
\text { units, } 10 \mathrm{~kb} \\
7 \mathrm{~kb}\end{array}$ & None & 14 & 18 & 4 & $\begin{array}{l}\text { - UL and LL girdle weakness } \\
\text { - Asymmetrical scapular winging } \\
\text { - Mild scoliosis }\end{array}$ & 685 & $\begin{array}{l}\text { Dystrophic } \\
\text { changes }\end{array}$ \\
\hline 5 & M & 43 & $\begin{array}{l}\text { Walk with } \\
\text { frame indoors, } \\
\text { wheelchair } \\
\text { outdoors }\end{array}$ & $\begin{array}{l}3 \pm 1 \mathrm{D} 4 \mathrm{Z4} \\
\text { units, } 17 \mathrm{~kb} \text {, } \\
14 \mathrm{~kb}\end{array}$ & None & 14 & 41 & 27 & $\begin{array}{l}\text { - UL girdle weakness with } \\
\text { scapular winging } \\
\text { - Increased LL weakness with age } \\
\text { - Required walking stick since age } \\
36 \text { years } \\
\text { - Used walking frame indoor and } \\
\text { wheelchair outdoor since age } \\
43 \text { years }\end{array}$ & 319 & Inadequate \\
\hline 6 & M & 47 & $\begin{array}{l}\text { Walk with stick } \\
\text { outdoors }\end{array}$ & $\begin{array}{l}4 \pm 1 \mathrm{D} 4 \mathrm{Z} 4 \\
\text { units, } 21 \mathrm{~kb} \\
18 \mathrm{~kb}\end{array}$ & Father & 11 & 46 & 35 & $\begin{array}{l}\text { - Facial weakness } \\
\text { - UL and LL girdle weakness } \\
\text { - Significant scapular winging } \\
\text { - Required walking stick since age } \\
47 \text { years }\end{array}$ & 708 & ND \\
\hline 7 & $M$ & 50 & $\begin{array}{l}\text { Walk with } \\
\text { stick indoors, } \\
\text { wheelchair } \\
\text { outdoors }\end{array}$ & $\begin{array}{l}2 \pm 1 \mathrm{D} 4 \mathrm{Z} 4 \\
\text { units, } 14 \mathrm{~kb} \\
11 \mathrm{~kb}\end{array}$ & None & 32 & 48 & 16 & $\begin{array}{l}\text { - Facial weakness } \\
\text { - UL and LL girdle weakness } \\
\text { - Significant scapular winging } \\
\text { - Required walking stick since age } \\
47 \text { years } \\
\text { - Used electric wheelchair since } \\
\text { age } 49 \text { years }\end{array}$ & 568 & $\begin{array}{l}\text { Non- } \\
\text { specific } \\
\text { myopathic } \\
\text { change }\end{array}$ \\
\hline 8 & $\mathrm{~F}$ & 65 & $\begin{array}{l}\text { Walk with } \\
\text { stick indoors, } \\
\text { wheelchair } \\
\text { outdoors }\end{array}$ & $\begin{array}{l}3 \pm 1 \mathrm{D} 4 \mathrm{Z} 4 \\
\text { units, } 18 \mathrm{~kb} \\
15 \mathrm{~kb}\end{array}$ & Daughter & 19 & 63 & 44 & $\begin{array}{l}\text { - Facial weakness } \\
\text { - Significant scapular winging } \\
\text { - Asymmetrical limb weakness } \\
\text { more on right side } \\
\text { - Increase LL weakness with age } \\
\text { - Required walking stick since age } \\
52 \text { years } \\
\text { - Used electric wheelchair since } \\
\text { age } 57 \text { years }\end{array}$ & 278 & ND \\
\hline
\end{tabular}

Abbreviations: $C K=$ creatine kinases; $L L=$ lower limb; $N D=$ not done; $U L=$ upper limb

* D4Z4 units $=($ EcoRI size minus 5) divided by 3.3. Normal individuals should have more than I0 D4Z4 units for each allele

All eight patients with FSHD1 had a significant $38 \%$ of our patients. Patients 1 and 4 inherited the contraction-from one to four units-of the D4Z4 autosomal dominant FSHD1 from their mildly repeats. There was no correlation between the symptomatic mother, as confirmed by genetic number of D4Z4 units and the age of onset or clinical testing. Patient 6 inherited the condition from his severity; Patients 1 and 7 both had two D4Z4 units, father. Patient 8 passed on FSHD1 to her daughter. but age of onset differed by 30 years.

Clinical variability and reduced penetrance were

A positive family history was observed in evident. 


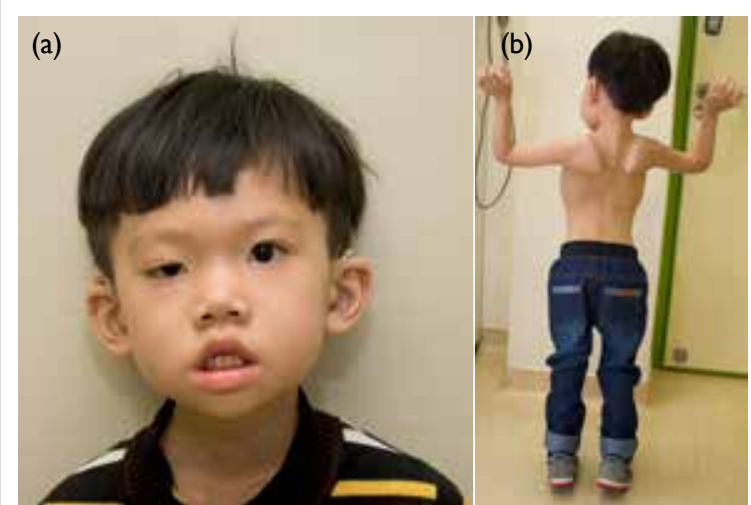

FIG I. Patient I.A 6-year-old boy presenting with early-onset facioscapulohumeral muscular dystrophy type I. Clinical photographs at age 3 years showing (a) right ptosis and facial weakness, more affected on the right side, and (b) significant bilateral winging of scapula and difficulty raising both arms above shoulder height. The patient stood with hyperlordotic back and had bilateral hearing aids

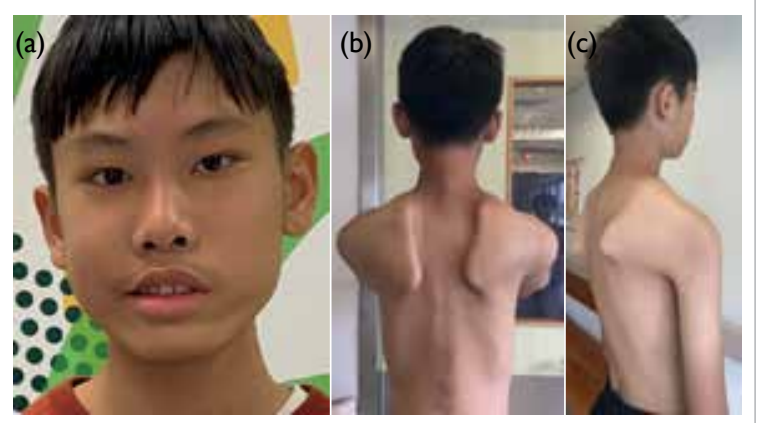

FIG 2. Patient 2.A I4-year-old boy who first presented with symptoms of facioscapulohumeral muscular dystrophy type I from age II years. Clinical photographs showing (a) asymmetrical facial weakness more on the left side, and (b, c) marked winging of scapula
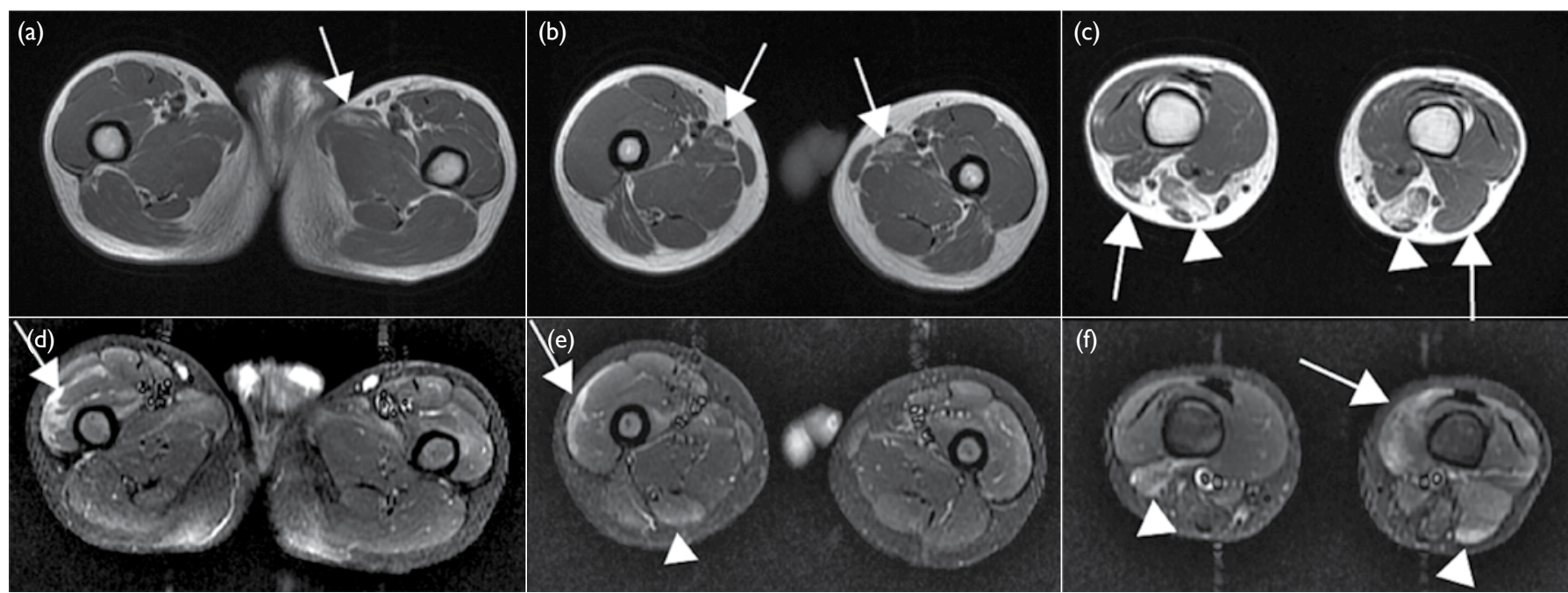

FIG 3. Patient 2.A I4-year-old boy who first presented with symptoms of facioscapulohumeral muscular dystrophy type I from age II years. (a-c) Axial TI-weighted and (d-f) short tau inversion recovery (STIR) magnetic resonance imaging scans of the thigh muscles from pelvis to lower thighs taken at age 13 years. (a) Focal fatty infiltration is noted at the left adductor longus, asymmetrically involving the left side (arrow). (b) Focal fatty infiltration is noted involving bilateral adductor longus asymmetrically, more severe on the left side (arrows). (c) More severe fatty infiltration involving posterior compartment of the thighs, particularly semimembranosus bilaterally (arrowheads), and right long head of biceps femoris (arrows) are seen. Discrepancy in size of the biceps femoris with the right side being smaller than left is also noted (arrows). (d) STIR hyperintensity changes are noted involving the right vastus lateralis (arrow). (e) STIR hyperintensity changes are also noted involving the right vastus lateralis (arrow) and to a lesser extent the right semitendinosus and right biceps femoris (arrowhead). (f) STIR hyperintensity changes involving the bilateral biceps femoris (arrowheads) and left vastus medialis (arrow) are also noted

\section{Discussion}

This is the first case series of genetically confirmed FSHD1 in Hong Kong. Worldwide, FSHD (OMIM No. 158900) is the third most common form of dystrophy, with a prevalence of 1:15000 to 1:20000. It can be classified as type 1 (FSHD1) or type 2 (FSHD2). Most patients with FSHD have FSHD1 (95\%) that has autosomal dominant inheritance.
Up to one third of cases are caused by de novo mutations. ${ }^{1}$

Typically, FSHD presents during the second or third decade of life as asymmetrical facial weakness followed by muscle weakness around the scapula and upper arms, then truncal and lower extremity weakness. Asymmetrical muscle involvement is typical. In all, $10 \%$ to $30 \%$ of individuals eventually 

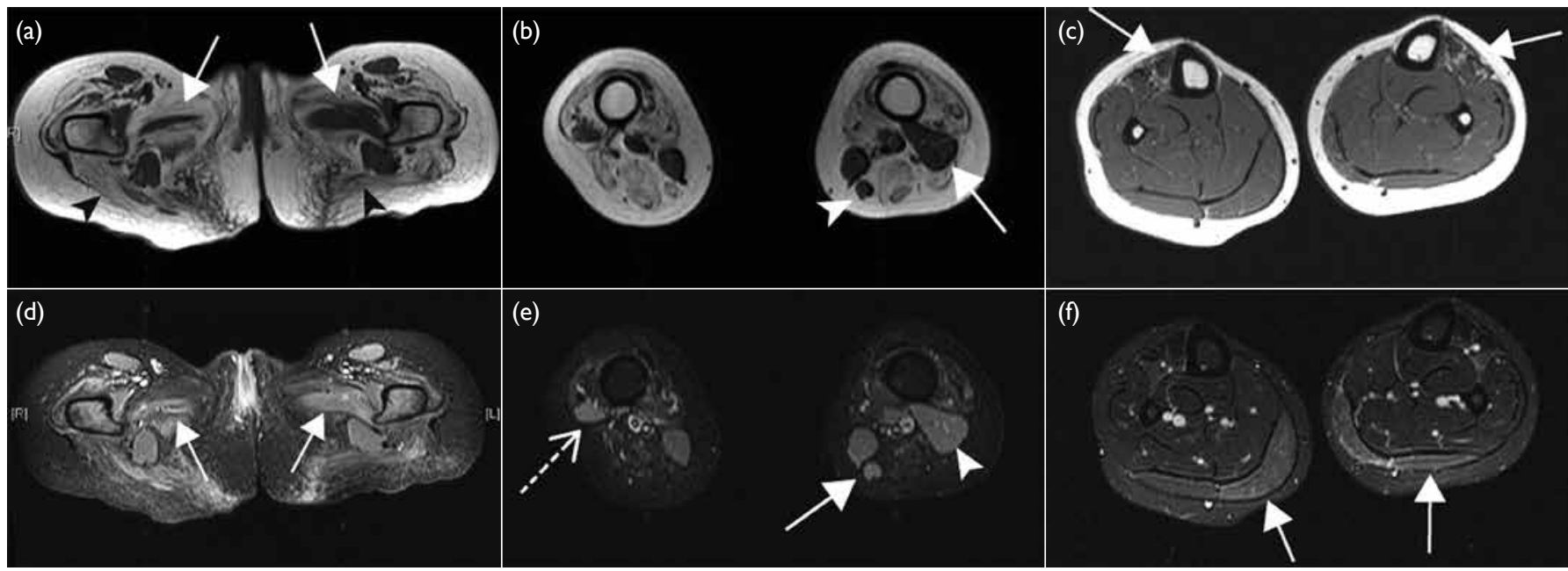

FIG 4. Patient 3.A woman who first presented with symptoms of facioscapulohumeral muscular dystrophy type I at age I8 years. (a-c) Axial TI weighted and (d-f) short tau inversion recovery (STIR) magnetic resonance imaging scans of the thigh muscles from pelvis to upper calves taken at age 23 years. (a) Bilateral TI-weighted hyperintensity indicating fatty infiltration, involving bilateral pectineus muscles (arrows) and gluteus maximus (arrowheads) with more severe involvement on the right side, is noted. (b) Diffuse fatty infiltration of the thigh muscles with atrophy, more severe on the right side, and discrepant circumference on two sides, is noted. There was relative sparing of the left gracilis (arrow) and left biceps femoris (arrowhead), but corresponding muscles on the right side are involved. (c) Atrophy of the left gastrocnemius is more evident compared to the right side. Fatty infiltration with atrophy of the tibialis anterior is noted bilaterally (arrows). (d) STIR hyperintensity changes are seen involving bilateral adductors (arrows). (e) STIR hyperintensity changes are seen involving the left biceps femoris (arrowhead), left gracilis and sartorius (arrow), and right vastus lateralis (dashed arrow) showing an asymmetrical pattern of involvement. (f) STIR hyperintensity changes involving the gastrocnemius bilaterally (arrows)

become non-ambulatory. Around 38\% of patients develop a restrictive lung disease pattern, and $1 \%$ to $3 \%$ eventually require ventilatory support.

Early-onset FSHD accounts for $10 \%$ of total FSHD. Affected individuals typically present with facial weakness before age 5 years and shoulder girdle weakness before age 10 years. Early-onset FSHD is generally associated with fewer D4Z4 repeats and higher disease severity. Patients often present with global developmental delays, dysarthria, dysphagia, intellectual disabilities, epilepsy, cochlear dysfunction, and retinal vasculopathy. ${ }^{2}$

The genetic mechanisms of FSHD1 are complex (Fig 5). Genetic diagnosis of FSHD1 typically involves the Southern blot technique or the molecular combing technique using fluorescence in situ hybridisation. ${ }^{3}$ Presently, specific genetic testing for FSHD1 is currently unavailable in the laboratories of the public healthcare system in Hong Kong.

There are several possible reasons for the delay in diagnosis in our cases. First, the lack of patient awareness of an underlying neuromuscular disease at their initial presentation often led to delayed consultation. Second, many doctors are unfamiliar with neuromuscular diseases with consequent delayed referrals. Most importantly, publicly funded genetic diagnostic testing for FSHD1 is currently unavailable. Most patients with a clinical suspicion of FSHD cannot afford expensive overseas genetic testing to confirm their diagnosis. Some patients with FSHD simply do not have the option of diagnosis.

Early molecular diagnosis of FSHD is crucial to enable timely assessment and management, including ophthalmic and hearing assessment in early-onset FSHD; regular motor, pulmonary and neuromuscular pain evaluations, referral for an aerobic exercise programme, and surgical scapular fixation if needed. Routine cardiac screening is unnecessary in the absence of cardiac symptoms. ${ }^{4}$ Early genetic diagnosis can also help to identify other affected or asymptomatic family members. Prenatal diagnosis in pregnancies of affected individuals provides couples with informed choices. Registries for patients with FSHD have been established in different countries to facilitate recruitment for clinical studies and trials.

The landscape of clinical trials is promising. A phase 2 study of losmapimod, an oral agent that inhibits and reduces the expression of myotoxic $D U X 4$, is currently underway. ${ }^{5}$

This study increases professional awareness of FSHD and highlights the importance of early recognition and diagnosis for this condition, as well as a current service gap in the genetic diagnosis of FSHD. Establishing a local registry will help recruit patients into clinical trials. 


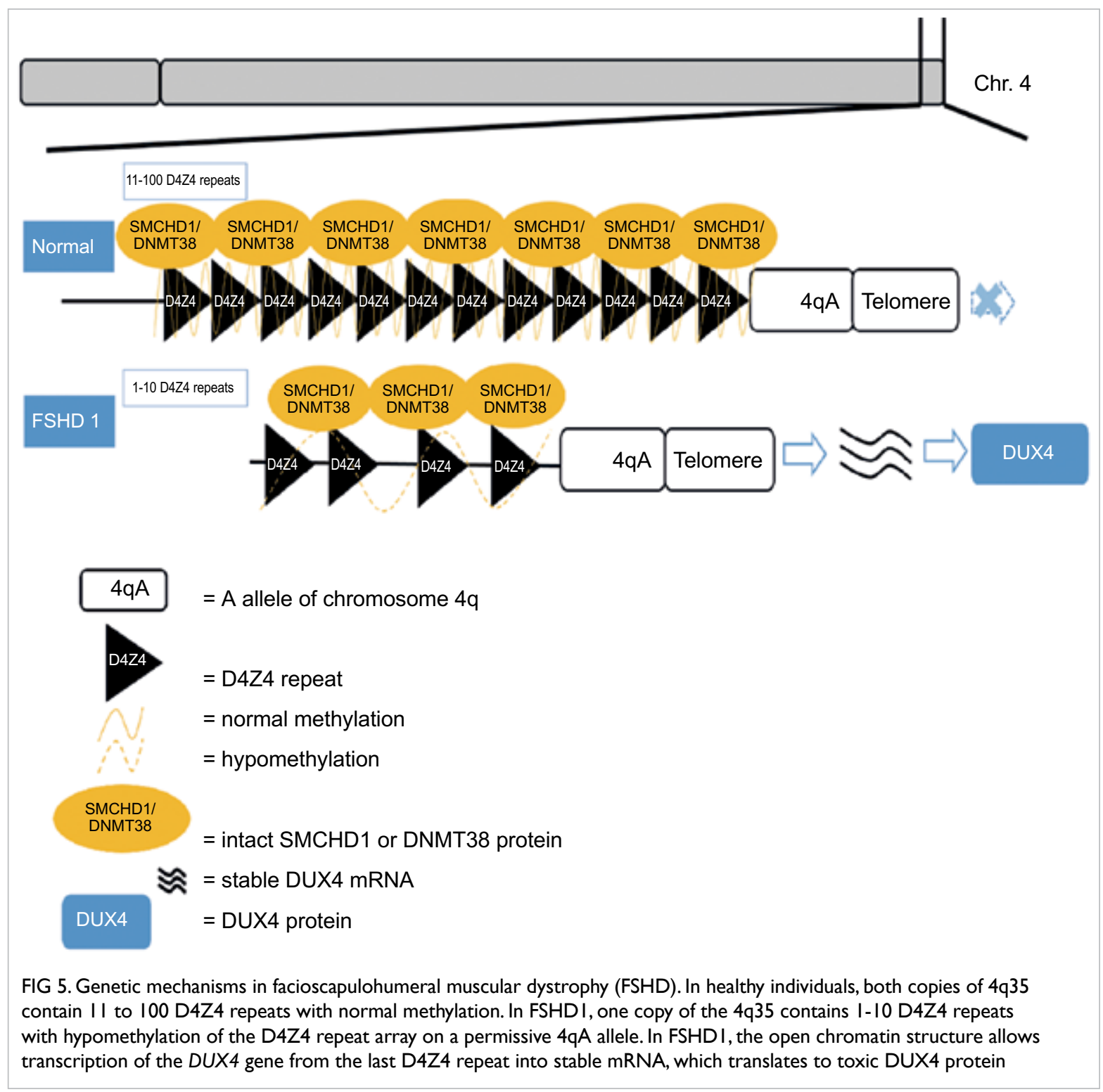

\section{Author contributions}

Concept or design: SHS Chan, WY Leung, HM Luk, V Vardhanabhuti.

Acquisition of data: All authors.

Analysis or interpretation of data: SHS Chan, WY Leung, HM Luk, V Vardhanabhuti, Yuan Gao.

Drafting of the manuscript: SHS Chan, WY Leung.

Critical revision of the manuscript for important intellectual content: All authors.

All authors had full access to the data, contributed to the study, approved the final version for publication, and take responsibility for its accuracy and integrity.

\section{Conflicts of interest}

All authors have disclosed no conflicts of interest.

\section{Acknowledgement}

The authors thank Professor Silvère M van der Maarel and Dr
R Lemmers of the Department of Human Genetics, Leiden University Medical Center, Leiden, The Netherlands, for their expert advice on the diagnosis of facioscapulohumeral dystrophy in the two paediatric patients. The authors also thank Ms Rachel BY Lee for editing the English in a draft of this manuscript.

\section{Funding/support}

This study was supported by donations from Mrs Yang to the 'Diagnosis and therapy development of rare neurological diseases and neuromuscular diseases' fund that provides financial support for overseas genetic testing for patients with facioscapulohumeral muscular dystrophy.

\section{Ethics approval}

This study was approved by the Hong Kong University Institutional Review Board (Ref: UW_20-405). All patients provided verbal consent to be included in this publication. Two patients (Patients 1 and 2) and their families provided written consent for the publication of clinical photographs. 


\section{References}

1. Sacconi S, Salviati L, Desnuelle C. Facioscapulohumeral muscular dystrophy. Biochim Biophys Acta 2015;1852:60714.

2. Mah JK, Chen YW. A pediatric review of facioscapulohumeral muscular dystrophy. J Pediatr Neurol 2018;16:222-31.

3. Lemmers RJ, O'Shea S, Padberg GW, Lunt PW, van der Maarel SM. Best practice guidelines on genetic diagnostics of Facioscapulohumeral muscular dystrophy: workshop 9th June 2010, LUMC, Leiden, The Netherlands. Neuromuscul Disord 2012;22:463-70.
4. Tawil R, Kissel JT, Heatwole C, et al. Evidencebased guideline summary: Evaluation, diagnosis, and management of facioscapulohumeral muscular dystrophy: Report of the Guideline Development, Dissemination, and Implementation Subcommittee of the American Academy of Neurology and the Practice Issues Review Panel of the American Association of Neuromuscular \& Electrodiagnostic Medicine. Neurology 2015;85:357-64.

5. Michelle Mellion M. Efficacy and safety of losmapimod in subjects with facioscapulohumeral muscular dystrophy (FSHD). Available from: https://clinicaltrials.gov/ct2/ show/NCT04003974. Accessed 2 Nov 2020. 